

Original Research Article

https://doi.org/10.20546/ijcmas.2017.605.036

\title{
Biofilm Producing Uropathogens and Drug Resistance: Dual Foe for Patients on Urinary Catheter
}

\author{
Ramya Amuthamani, Anandhalakshmi Subramaniyan* and Reba Kanungo \\ Pondicherry Institute of Medical Sciences Kanapathichettikulam Puducherry 605014, India
}

*Corresponding author

\begin{tabular}{|c|c|}
\hline & A B S T R A C T \\
\hline & \multirow{6}{*}{$\begin{array}{l}\text { Microbial biofilms in indwelling urinary catheters promote persistent and recurrent } \\
\text { infections. This is due to their complex nature and resistance to commonly used antibiotics } \\
\text { that are a challenge to management of catheter associated urinary tract infection (CAUTI). } \\
\text { The present study was conducted to detect biofilm production by isolates from patients } \\
\text { with CAUTI, and their association with antibiotic resistance. A prospective study was } \\
\text { done on } 344 \text { hospitalized patients in intensive care units, with indwelling urinary catheter } \\
\text { of more than 2days. CAUTI was diagnosed based on the CDC guidelines } 2015 \text {. } \\
\text { Uropathogens were identified and their antibiotic susceptibility was performed following } \\
\text { standard microbiological methods. Biofilm detection was done by tube adherence method. } \\
\text { Proportion and percentages, and fisher exact test were used to analyse the results. Among } \\
344 \text { patients catheterised, } 41 \text { developed CAUTI. The most common organism isolated was } \\
\text { E.coli (51.2\%), followed by Klebsiella pneumoniae ( } 24.4 \%) \text {. Among the isolates } 29 \text { ( } 71 \% \text { ) } \\
\text { were biofilm producers. Biofilm producing strains showed relatively higher antibiotic } \\
\text { resistance than non-producers. Among the } 66 \% \text { of multi drug resistant (MDR) isolates, } \\
64 \% \text { were biofilm producers, showing significant association between biofilm production } \\
\text { and multidrug resistance. There was statistical significance between patients on long term } \\
\text { antibiotics ( }>5 \text { days) and the development of MDR infection in them. (p<0.027). Increased } \\
\text { prevalence of MDR among biofilm producers was significant posing a problem in CAUTI } \\
\text { management. Biofilms producers, are highly resistant to several conventional management } \\
\text { approaches. Hence newer management strategies may be needed. }\end{array}$} \\
\hline Keywords & \\
\hline $\begin{array}{l}\text { CAUTI, Biofilm, } \\
\text { Multidrug } \\
\text { resistance. }\end{array}$ & \\
\hline Article Info & \\
\hline $\begin{array}{l}\text { Accepted: } \\
\text { 04 April } 2017 \\
\text { Available Online: } \\
10 \text { May } 2017\end{array}$ & \\
\hline & \\
\hline
\end{tabular}

\section{Introduction}

Catheter associated urinary tract infection (CAUTI) occurs because urethral catheters seed bacteria into bladder and promote colonization by providing a platform for bacterial adherence (Vergidis and Patel, 2012). The organisms which commonly contaminate the catheters produce biofilm. Biofilms are the microbial communities of the surface attached cells which are embedded in a self-produced extracellular polymeric
Matrix (Donlan and Costerton, 2002; Vergidis and Patel, 2012). The biofilms have major medical significance as they decrease the susceptibility to the anti-microbial agents (Watnick and Kolter, 2000). CAUTI are associated with recurrences and complications hence pose a major health concern. Left untreated, these infections can lead to urosepsis and death (Niel-Weise and van den Broek, 2005). 
Research directed at detection of prevalence of pathogens, their susceptibility patterns and biofilm formation of the isolates causing CAUTIs is currently underway. The biofilms have major medical significance as they decrease the susceptibility to the antimicrobial agents.

Furthermore, the speed of antimicrobial resistance is enhanced by the plasmid exchange between the cells due to their close proximity. The present study was conducted to detect biofilm production by isolates from CAUTI and their association with antibiotic resistance. Duration of catheterisation, risk factors and co-morbid conditions associated with CAUTI were also analysed.

\section{Materials and Methods}

The study was approved by the Institutional Ethics Committee (IEC). A total of 344 patients were on catheter were recruited into the study over 3 months. The diagnosis of CAUTI was made based CDC guideline 2015 (CDC, 2012). i.e. those on indwelling urinary catheters for at least 2 days plus any one of the following symptoms of UTIs (fever > $38^{\circ} \mathrm{C}$, urgency, frequency, dysuria or suprapubic tenderness) and presence significant bacteruria and a positive urine culture by standard methods followed by antibiotic susceptible test. The detection of biofilm was done by the Tube adherence method

Tube adherence method by Christensen et al., briefly the method was as follows:

The test strains were inoculated in glass tubes which containing Brain Heart Infusion Broth (broth) aerobically at a temperature of $37^{\circ} \mathrm{C}$ for 48 hours. Liquid culture was discarded and the tubes were stained with a $0.1 \%$ Safranin solution. The tubes were then washed with distilled water thrice and dried. Presence of a layer of stained material adhering to the wall of the tube was taken as positive. (Christensen GD 1982)

\section{Results and Discussion}

Out of 344 patients on catheter during the study period, 41 (12\% with $95 \%$ confidence interval-CI - 8.7\%-15.9\%). developed CAUTI. The most common organism isolated was E. coli (51.2\%) followed by Klebsiella pneumoniae (24.4\%), Pseudomonas aeruginosa (9.8\%), Enterococcus faecalis (9.8\%), Proteus mirabilis (2.4\%) and Acinetobacter baumannii (2.4\%). Twenty nine (71\%) were found to be positive for biofilm production by tube adherence method. Table 1 shows the biofilm producers among bacterial isolates.

Antibiotic sensitivity patterns of biofilm producing strains displayed a relatively higher resistance against tested antibiotics. Figure 1 shows resistance pattern among the isolates including biofilm producers and biofilm non producers.

Sixty six percent of the isolates were multi drug resistant with, 64\% (95\% CI $=42.6 \%$ $81.2 \%$ ) of them were biofilm producers, showing significant correlation between biofilm production and multidrug resistance (Figure 2). Duration of antibiotic intake for $<5$ days, $\geq 5$ days - long term antibiotic and association with MDR was found to be statistically significant $\mathrm{P}<0.027$ (Table 2). CAUTI is the most common nosocomial infection and comprising $>40 \%$ of all hospital acquired infections (Lewis et al., 2013). CAUTI common in elderly is attributed to the increase prevalence of other morbidity factors requiring prolonged catheterization like diabetes mellitus, hypertension, chronic kidney disease and cerebrovascular accident (Madigan and Neff, 2003; Stevens Viswanathan and Weiner, 2010) In the present study majority of the patients were $>60$ years ( $50 \%$ of the study population). 
Table.1 Biofilm producers among the bacterial isolates

\begin{tabular}{|l|c|c|}
\hline Bacterial isolates & $\begin{array}{l}\text { Biofilm } \\
\text { producers }\end{array}$ & Total n=41 \\
\hline Escherichia coli & $13(57 \%)$ & $21(51.2 \%)$ \\
\hline $\begin{array}{l}\text { Klebsiella } \\
\text { pneumoniae }\end{array}$ & $6(56 \%)$ & $10(24 \%)$ \\
\hline $\begin{array}{l}\text { Pseudomonas } \\
\text { aeruginosa }\end{array}$ & $2(50 \%)$ & $4(10 \%)$ \\
\hline Proteus mirabilis & $1(100 \%)$ & $1(2 \%)$ \\
\hline Enterococcus faecalis & $2(33 \%)$ & $4(10 \%)$ \\
\hline $\begin{array}{l}\text { Acinetobacter } \\
\text { baumannii }\end{array}$ & $0(0 \%)$ & $1(2 \%)$ \\
\hline
\end{tabular}

Table.2 Association between patients on ( $>5$ days) long term antibiotics and MDR development

\begin{tabular}{|l|l|l|l|}
\hline & $\begin{array}{l}\text { Patients on antibiotics } \\
<5 \text { days. }\end{array}$ & $\begin{array}{l}\text { Patients on long term } \\
\text { antibiotics } \geq 5 \text { days }\end{array}$ & Total \\
\hline MDR & 12 & 10 & 22 \\
\hline Non MDR & 12 & 1 & 13 \\
\hline Total & 24 & 11 & 35 \\
\hline
\end{tabular}

Statistical test: Fisher's Exact test, significant $p$ value $<0.0270$

Figure.1 Antibiotic resistance pattern among gram negative biofilm producers and nonproducers

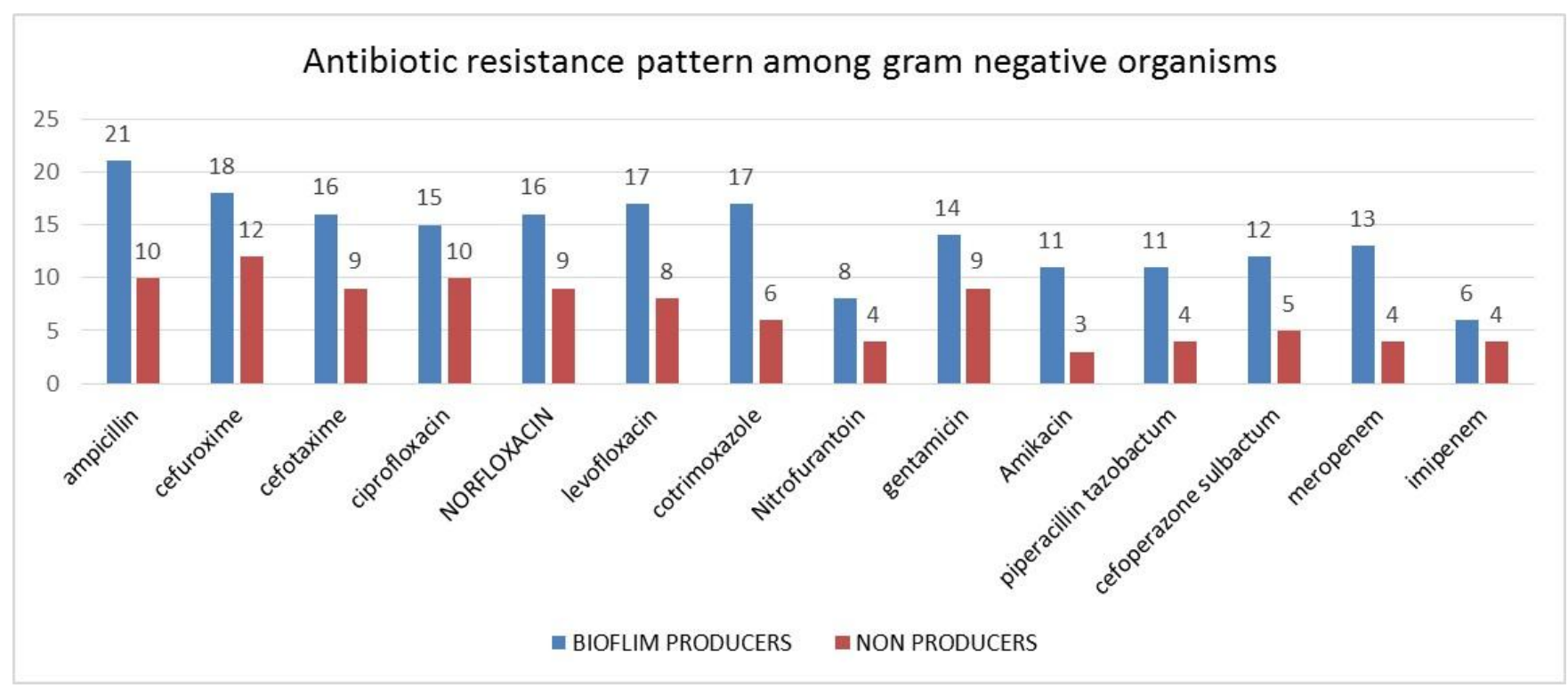


Figure.2 Association between biofilm producers and MDR

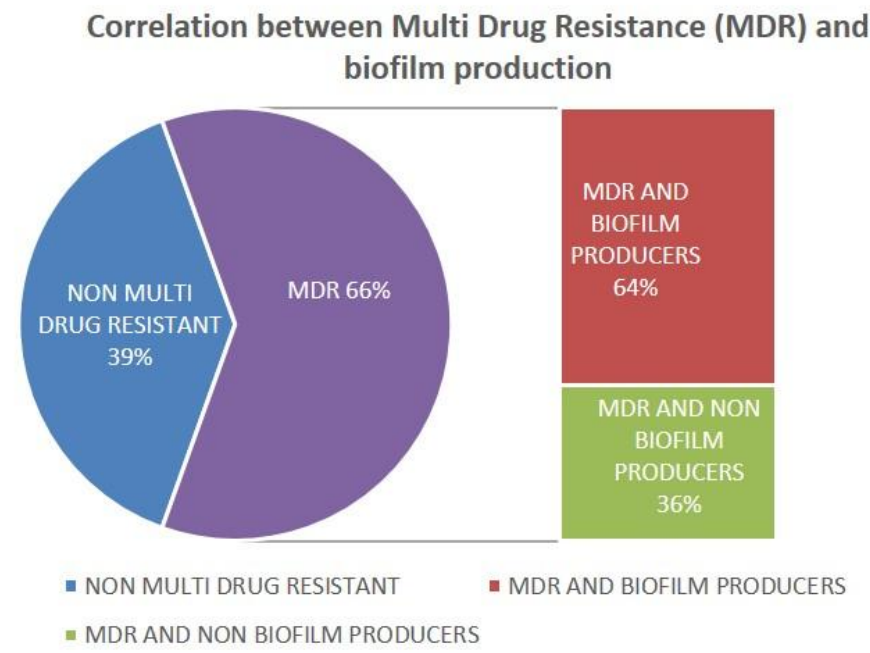

The present study showed out of the 41 strains, E. coli was the most frequently isolated pathogen $(51.2 \%)$ followed by Klebsiella pneumonia (24.4\%). This finding correlated with few other previous studies (Hassin 1991; Niveditha et al., 2012; Sayal et al., 2014). The presence and expression of various virulence factors like, adhesions (e.g., type 1 and $P$. fimbriae) and toxins (e.g., haemolysin) are responsible for uropathogenic $E$. coli to be the most common cause of UTI (Bien et al., 2012; Reisner et al., 2014).

Formation of biofilm along the catheter surface is a contributing factor for chronic, indolent infection in CAUTI. Out of the 41 isolates, $29(71 \%)$ were found to be positive for biofilm production. Studies done by Sayal et al., (2014) and Pramodhini et al., (2012) had similar results of $71 \%$ and $60 \%$ biofilm production.

The microbial biofilms are associated with persistent infections which do not respond to the conventional antibiotic therapy (Donlan and Costerton, 2002). They are protected from antimicrobial chemotherapy as well as host defence mechanisms. In this study $66 \%$ of the isolates obtained were multi drug resistant.

Among the $66 \%$ of multi drug resistant isolates, $64 \%$ were biofilm producers. This finding indicates that larger percentage of biofilm producers may be multidrug resistant. It was also found that there was significant correlation $(p=0.27)$ between patient on long term antibiotic and infection with MDR isolates. Catheter care and frequent change would increase the response to antibiotic therapy (Trautner and Darouiche, 2004).

In conclusion there is a need to understand the mechanism of biofilm production to prevent it, and institute standard catheter care practices with a view to prevent CAUTI. Biofilm producers, are highly resistant to several antibiotics as opposed to planktonic cells. Hence newer management strategies need to be explored.

Biofilm plays a major role in the pathogenesis of CAUTI. The diagnosis, management and prevention of CAUTI are prejudiced by the persistence of biofilm- producing uropathogens. 


\section{Acknowledgement}

Special thanks to ICMR for granting the ICMR STS 2015 (ID: 2015-00602) scholarship for this project.

\section{References}

Bien, J., Sokolova, O., \& Bozko, P. 2012. "Role of uropathogenic Escherichia coli virulence factors in development of urinary tract infection and kidney damage", Int. J. Nephrol., vol. 2012.

CDC. 2012. Catheter associated urinary tract infection (CAUTI) event, Center for Dis. Control and Prevention.

Christensen, G.D., S.W.B.A.B.E.H. 1982. "Adherence of slime-producing strains of Staphylococcus epidermidis to smooth surfaces", Infect Immun., vol. 37, no. 1, pp. 318-326.

Donlan, R.M. \& Costerton, J.W. 2002. "Biofilms: survival mechanisms of clinically relevant microorganisms", Clin. Microbiol. Rev., vol. 15, no. 2, pp. 167-193.

Hassin, S.K.R. 1991. "Studies on urinary tract infections", Bangladesh Med. J., vol. 20, no. 1, pp. 29-32.

Lewis, S.S., Knelson, L.P., Moehring, R.W., Chen, L.F., Sexton, D.J., \& Anderson, D.J. 2013. "Comparison of Non GÇô Intensive Care Unit (ICU) versus ICU Rates of Catheter-Associated Urinary Tract Infection in Community Hospitals", Infection control and hospital epidemiology: the official Journal of the Society of Hospital Epidemiologists of America, vol. 34, no. 7, pp. 744-747.

Madigan, E. and Neff, D.F. 2003. "Care of patients with long-term indwelling urinary catheters", Online J. Issues Nurs., vol. 8, no. 3, p. 7.

Niel-Weise, B.S. and van den Broek, P.J. 2005,
"Urinary catheter policies for long-term bladder drainage", Cochrane. Database Syst. Rev., no. 1, p. CD004201.

Niveditha, S., Pramodhini, S., Umadevi, S., Kumar, S., \& Stephen, S. 2012. "The isolation and the biofilm formation of uropathogens in the patients with catheter associated urinary tract infections (UTIs)", J. Clin. Diag. Res. $J C D R$, vol. 6, no. 9, p. 1478.

Pramodhini, S., Niveditha, S., Umadevi, S., Kumar, S., \& Stephen, S. 2012. "Antiobiotic resistance pattern of biofilm-forming uropathogens isolated from catheterised patients in Pondicherry, India", Australasian Med. J., vol. 5, no. 7.

Reisner, A., Maierl, M., Jarger, M., Krause, R., Berger, D., Haid, A., Tesic, D., \& Zechner, E.L. 2014. "Type 1 Fimbriae Contribute to Catheter-Associated Urinary Tract Infections Caused by Escherichia coli", J. Bacteriol., vol. 196, no. 5, pp. 931-939.

Sayal, P., Singh, K., \& Devi, P. 2014. "Detection of Bacterial Biofilm in Patients with Indwelling Urinary Catheters", CIB Tech. J. Microbiol., vol. Vol. 3(3), pp. 9-16.

Stevens, L.A., Viswanathan, G., \& Weiner, D. E. 2010. "CKD and ESRD in the Elderly: Current Prevalence, Future Projections, and Clinical Significance", Advances in Chronic Kidney Dis., vol. 17, no. 4, pp. 293-301.

Trautner, B.W. and Darouiche, R.O. 2004. "Role of biofilm in catheter-associated urinary tract infection", American J. Infect. Control, vol. 32, no. 3, pp. 177-183.

Vergidis, P. and Patel, R. 2012. "Novel approaches to the diagnosis, prevention, and treatment of medical device-associated infections", Infect. Dis. Clin. North Am., vol. 26, no. 1, pp. 173-186.

Watnick, P. and Kolter, R. 2000. "Biofilm, city of microbes", J. Bacteriol., vol. 182, no. 10, pp. 2675-2679.

\section{How to cite this article:}

Ramya Amuthamani, Anandhalakshmi Subramaniyan and Reba Kanungo. 2017. Biofilm Producing Uropathogens and Drug Resistance: Dual Foe for Patients on Urinary Catheter. Int.J.Curr.Microbiol.App.Sci. 6(5): 326-330. doi: http://dx.doi.org/10.20546/ijcmas.2017.605.036 